\title{
US panel to back longer cloning ban, ducks thornier questions
}

[WASHINGTON] A US presidential advisory commission on bioethics is expected to recommend the continuation of a ban on the use of federal funds "for cloning of human beings" when it reports at the end of this month. The ban was initially declared by President Bill Clinton in March.

Extending the ban, according to members of the National Bioethics Advisory Commission (NBAC), will give US policymakers and their advisers time to address and consult on the complex web of scientific, political and ethical issues raised by cloning.

According to one member of the commission, David Cox, a geneticist at Stanford Medical School, "[h]ow much of a stick to use and what stick to use is a complicated issue". He says that preserving the existing ban will buy time for "a more thorough national discussion".

The commission appears unanimous in its opposition to any use of newly discovered cloning technology to produce living humans. But separately, commissioners, while conceding the value of human cellularlevel research that could profit from the new

technology, appear unlikely to try to protect it.

This is because it would breach a twoyear-old congressional prohibition of federal funding of human embryo research. "This is not the time to revisit [the human embryo research issue]," said Harold Shapiro, NBAC chairman and the president of Princeton University, at an NBAC meeting on 2 May.

The new Clinton ban on government funding "for cloning of human beings" was in response to the publication of results of experiments in which researchers at Edinburgh's Roslin Institute cloned a sheep from a mammary cell of an adult ewe (see Nature 385, 810-813; 1997). On hearing the news, Clinton also asked the commission to complete within 90 days "a thorough review of the legal and ethical issues" associated with the new cloning technology and to recommend "possible federal actions" to prevent its abuse.

With the 90-day deadline fast approaching, the 18-member commission appears to have reached a level of agreement. "The minimum is a continued moratorium on cloning of human beings for implantation," says Ezekiel Emanuel, an associate professor of

\section{Roslin patents come under the spotlight}

[PARIS] Embarrassment levels were high last week at the Roslin Institute in Edinburgh, which cloned Dolly the sheep, after it emerged that patents on the technology filed by the institute would cover all 'animals', including humans. The institute has taken a prominent stand against any attempt to use the technique to clone humans.

The scope of the patent applications was pointed out in a statement issued on 9

May by Rural Advancement Foundation International (RAFI), an Ottowa-based organization. If granted, the patents would represent "implicit acceptance of human cloning", says Hope Shand, research director of RAFI

The patent applications have been registered at the World Intellectual Property Organization in Geneva, Switzerland, and will now go to patent offices in Europe, the United States and elsewhere for examination - the approval process will take several years. Shand says that RAFI's statement is intended as a pre-emptive strike aimed at creating public awareness. She asserts that patent offices otherwise risked "blindly accepting" the patents with their current scope.

Shand hopes that patent offices will now restrict the scope of such patents. She also expresses the widely held sentiment that decisions on such moral choices should not be left to patent offices, but should rather be the subject of international agreements.

Indeed, one outcome of the debate about human cloning has been to trigger a broad consensus on the need for such agreements in bioethics. Recommendations aimed at international regulation of cloning were expected from the International Bioethics
Committee of the United Nations Educational, Scientific and Cultural Organization this week. Harry Griffins, assistant director of the Roslin Institute, says the inclusion of humans in the patents was inadvertent. "Our intention at that time was to cover everything from farm animals to lab animals," he says. "It wasn't the intention to include humans."

$\mathrm{He}$ also retracts earlier statements in which he asserted that the scope of the patents would allow the Roslin Institute to prevent the technology falling into the wrong hands. He claims that these were off-the-cuff remarks. His statement had been pounced on by RAFI, who said it would be wrong to entrust the "ethics and fate of human cloning" to a single institute, and intends to mount a challenge against the patents. Declan Butler

\section{IMAGE UNAVAILABLE FOR COPYRIGHT REASONS}

Where it all began: the birth of Dolly (left) continues to stir international controversy.

medicine at the Dana-Farber Cancer Institute in Boston. The real issue, he says, is whether the recommendation "is going to be stronger than that or not - and how".

Some argue that backing the presidential ban is a risk-free move. For example, Arthur Caplan, director of the Center for Bioethics at the University of Pennsylvania Medical Center in Philadelphia, says the recommendation is "possible but meaningless", as "no one has any plans" to experiment with human cloning in the near future.

Indeed, most commissioners appear keen to pronounce on more than simply federally funded activities. Laurie Flynn, executive director of the National Alliance for the Mentally Ill, and an NBAC member, says " $[t]$ he looming concern about the private sector" dictates that "we have to speak to that directly and clearly".

Beyond urging a continued federal funding ban, the commission is considering two main policy options. The first would be a legislative ban on all cloning for implantation. The second is a continued ban on federal funding for such work, coupled with exhortations to the private sector to abstain voluntarily from such work, and to state licensing boards and professional societies to issue pronouncements againstit.

It is hoped that such pronouncements would deter private experimentation through establishing standards for malpractice lawsuits. But commission members concede that relying on a voluntary ban would present risks. The history of private fertility clinics has shown their operators to be "not a very trustworthy lot", says Emanuel.

Other NBAC members have argued that a ban imposed through federal legislation would have the advantage of clarity, comprehensive coverage of public and private sectors 